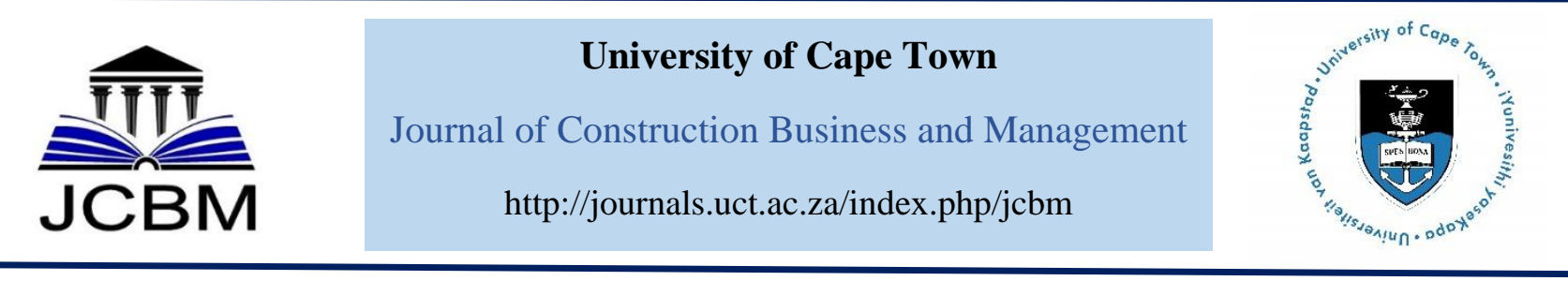

\title{
Subcontracting Systems and Social Protection in the Informal Building Construction Industry in Lagos, Nigeria
}

\author{
O. A. Olusanya ${ }^{1}$ \\ Department of Employment Relations and Human Resource Management, University of Lagos, Nigeria ${ }^{1}$
}

Received 28 April 2017; received in revised form 19 June 2017; accepted 3 July 2017

\begin{abstract}
Subcontracting systems are entrenched in the building construction process in Nigeria. However, the implications for informal building construction industry workers' access to social protection measures are a cause for concern. This study examined the influence of subcontracting systems on access to social protection measures by workers in the informal building construction industry in Lagos, Nigeria, based on a cross-sectional research design, agency theory and the general theory of employment. The secondary and primary data used for the study were derived from a systematic review of relevant literature, a questionnaire administered to 908 respondents and 50 key informant interviews among informal building construction workers and subcontractors. The structured questionnaire was subjected to internal and external validity; the Cronbach's Alpha reliability test of the survey stood at 0.722 . Data extracted from the structured questionnaire and interviews were analysed through the use of descriptive statistics, correlational analysis and narrative analysis. Findings revealed that workers got financial and health assistance from employers and government respectively. Results also show that informal building construction workers perceived provision of social protection as inadequate. The results of Pearson Correlation indicate that subcontracting systems have an inverse and statistically significant relationship with access to free or subsidised medical care, the remedy to accident on site and pattern of savings. Therefore, subcontracting systems influenced the availability of social protection measures significantly. Based on the findings and the important roles of subcontractors in the building construction industry, it is recommended that appropriate legislative instrument should be developed to address the challenges posed by subcontracting concerning access to social protection measures in the informal building construction industry. It is also suggested that steps should be taken by the government to promote formalisation of employment in the informal sector and support community-based social insurance schemes in Nigeria.
\end{abstract}

Keywords: Building construction, Informal economy, Lagos, Social protection, Subcontracting systems.

\section{Introduction}

Subcontracting systems are entrenched in the building construction process in Nigeria. The prevalence of subcontracting systems in the building construction industry has been referenced as a coping mechanism against uncertainties associated with the availability of resources, as well as site and climatic conditions (Usdiken, Sozen, \& Enbiyaoglu, 1988: 633). Subcontracting systems facilitate the engagement of subcontractors, who sometimes operate in the informal economy. Informality in employment in the building construction industry is observable in most developing countries (Wells, 2007: 91). The informal sector is the term used to describe informal employment within and outside of formal organisations covering informal selfemployment and informal wage employment (Chen, Vanek \& Heintz 2006: 2132).

Studies have shown that research on employment in developing countries would be inadequate unless necessary attention is given to the informal economy due to increased economic activities in the sector (Heintz \& Valodia, 2008: 11-12; Tanzi, 1999: 338). In this connection, the rate of employment generation in the Nigerian informal economy is estimated at between $45 \%$ and $60 \%$ of the urban labour force (Adejumo \& Azuh, 2013: 10). As at the last quarter of 2015 and the first three months of 2016, 61,026 informal sector jobs were generated in contrast with 21,477 formal sector employment in Nigeria (National Bureau of Statistics,

\footnotetext{
${ }^{1}$ Corresponding Author. Tel: +2348037188153

Email address: oaolusanya@unilag.edu.ng
} 
2016: 3). This statistic shows that more jobs are produced in the informal sector, suggesting that the sector should be a major target for social protection measures.

The goal of social protection measures is to ensure stable income to workers, alleviate poverty and risks associated with poverty (Barrientos \& Hulme, 2008: 2; ILO, 2000: 2). Moreover, social protection is believed to have contributed significantly to poverty reduction in developed and developing countries in the last 50 years (ILO, 2000: 2). Nevertheless, workers in the informal economy are more susceptible to inadequacies in employment than those in the formal sector, particularly because the former is unregulated (Akinwale, 2014: 118; Wamuthenya, 2010: 18).

The combination of subcontracting systems, with its attendant challenges for workers as well as short attention to the provision of social protection measures for informal workers in Nigeria, has necessitated this present study. Besides, Canagarajah and Sethuraman (2001: 22) suggested that provision of social security for informal workers is challenged by risks associated with the status of informality in employment. Therefore, the test of effectiveness and improvement of social protection can only be done by studying those who do not seem to benefit from the programme.

In the light of the above, the objective of this study is to assess the relationship between subcontracting systems and access of informal building construction industry workers to social protection measures in Lagos State, Nigeria. The study will answer three questions: (1) How do subcontracting systems relate to social protection measures in the informal building construction industry? (2) What types of assistance and benefits do informal building construction workers receive from the government? (3) What are the kinds of assistance provided by employers for informal building construction workers? The answers to these questions would provide insight into the nature of interventions required for social protection in the building construction industry.

The paper is divided into six major sections: section one deals with the introduction, section two addresses theoretical framework, relevant literature on subcontracting systems and social protection, section three covers methods, section four treats results and discussions, Section five treats conclusion and recommendation, and limitations of the study are discussed in section six.

\section{Review of Relevant Literature}

\subsection{Theoretical framework}

This study examines the relationship between sub contracting systems and availability of social protection measures in the informal building construction industry within the ambits of agency theory and the general theory of employment.

\subsection{Agency theory}

Agency theory originated from studies by Wilson (1968) and Arrow (1971) on the risk and challenge of differing disposition to risk sharing in work requiring some level of cooperation (Eisenhardt, 1989: 58). Agency theory offers explanation for the type of relationship where one party (the principal) delegates work to another (the agent) who possesses specialised knowledge/skills; and performs work on behalf of the principal (Jensen \& Meckling, 1976: 309; Eisenhardt, 1989: 59; Boland, Golden \& Tsoodle, 2008: 624; Cohen \& Baruch, 2010: 187). In this connection, agency theory can be utilised in the analysis of the conflict between principal and agent due to differing goals or desires and for the challenges associated with the disposition to risks. Thus, agency theory is useful in the analysis of principal-agent relations, which describes what a building construction contractor or project owner is to a worker or subcontractor respectively. Kallay (2012: 44) loosely defined agency theory as an interconnection of contracts between resource holders. As such, the nature and character of the agency relationship are defined by contracts. The implication of this is that if an employment contract does not provide for workers to access social protection or any other benefit, then employees may not be able to access whatever is not specified in a contract.

Agency relationships are characterised by conflicting goals between the principal and the agent, on the one hand, and the existence of asymmetric information, which makes monitoring and verification between the principal and agent difficult (Jensen \& Meckling, 1976: 311; Eisenhardt, 1989: 58). Therefore, the challenge of differing aims of parties to agency relationships, further aggravated by a gap in communication, may make concerns for social protection receive less attention in the context of subcontracting systems. The informality of employment in the building construction industry, which may account for the state of social protection measures in the sector is not covered by agency theory, and this necessitates the introduction of the general theory of employment into this discussion.

\subsection{The general theory of employment}

The general theory of employment is associated with John Maynard Keynes, author of General Theory of Employment, Interest and Money (1936). Deduced from Keynes' main argument is the fact that employment is not always full and permanent. This is a departure from the ideas put forward by classical economists, such as Say (1834), Ricardo (1817, 1971), Mill (1808, 1844, 1848), Marshall (1890) and Pigou (1912, 1944). The classical theory of employment believes that people work if their pay is worth the effort on the job in the labour market.

The classical economists argue that when the demand and supply of labour become equal, an economy will inevitably tend toward full employment (Gasset, n.d: 197). Full employment is when everyone who wishes to work is employed at a particular wage. However, one case of employment that is not full is known as non-standard employment. The non-standard employment situation is employment that is not continuous and full-time; without a contract specifying the duration of employment; without regular hours of work and associated benefits besides pay (Okafor, 2012: 103; Simons \& Lake, 2005: 4). The shortterm engagement of workers due to the nature of building construction work is often the rationale for adopting subcontract systems which invariably limits the obligations of contractors or whoever is the principal to workers. Therefore, Keynes' general theory of 
employment advocates legislative intervention, which could translate into social protection programmes.

The argument of the classical economists suggests that there is no chance that individuals may be involuntarily unemployed because they simply cannot find work even though they are willing to work at the prevailing wage. In this connection, the general theory of employment recommends that people must be ready to work for less pay. This recommendation may imply that involving subcontractors in the value chain of a business endeavour may force people to work for less and limit their access to social protection measures.

\subsection{Subcontracting systems in the building construction industry}

Subcontracting is the means by which individuals or firms purchase part of a product or process to optimise limited resources (Ajayi, 2007: 149; Kimura, 2002: 163). Subcontracting involves subletting the execution of a section or sections of a project to a contractor or contractors who specialise in specific aspects of the project (Manu, Ankrah, Proverbs, Suresh \& Adukpo, 2011: 736). Subcontracting systems have been described as an efficient risk-sharing mechanism, as individuals or organisations that choose to subcontract do so after weighing various options (Atamturk \& Hochbaum, 2001: 1081; Kimura, 2002: 166). It may be argued that subcontracting help firms to concentrate on core competencies.

Subcontracting systems and subcontractors have an important place in the construction industry (Azari-Rad, Philips \& Thompson-Dawson 2014: 242; Enshassi, Choudhry, Mayer \& Shoman, 2008: 52). The fragmented and specialised nature of construction work necessitates the engagement of different skills required at various times in the building process (ILO, 2001: 24). As such, subcontractors supply the necessary expertise and workers for construction work in the building construction process. It has been argued that subcontracting in the construction industry serves as a buffer against risk, helps to reduce operating costs, secure competitive advantage and position for maximum profit (Aronson \& Zionts, 2008: 232; Ohnuma, Pereira \& Cardoso, 2000: 2; Tanaka, 2012: 97). This offers some insight into the appeal of subcontracting systems for principals.

Subcontracting in the production sector in Nigeria commenced in the 1960s (Ajayi, 2007: 149). Subcontracting has been found to thrive in the Nigerian building construction industry, and some studies have examined its relevance in the industry. Adenuga (2013: 336) assessed how subcontractors affect quality in the delivery of construction projects; Ogunsanmi (2015: 64) examined subcontractor control in labour subcontracting and direct labour systems and found that there is less risk of premature delivery of the project in labour-only subcontracting. Furthermore, Fagbenle and Adesanya (2014: 300) examined the relationship between registration and performance of subcontractors and concluded that registration with the Federal Registration Board has no relevance to subcontractor performance and that registration is not a prerequisite for engagement. However, Loh and Ofori (2000) cited in Fagbenle and
Adesanya (2014: 297) determined that in Singapore the registration of subcontractors would improve the welfare of workers.

The focus and outcomes of these studies show that available studies on subcontracting systems in the Nigerian building construction industry do not provide adequate information about the relationship between subcontracting systems and social protection in the industry.

\subsection{Social protection in Nigeria}

Social protection, in the contemporary sense, has been noticeable since the 19th century, a time characterised by the commodification of labour, which exposed labour to new risks associated with mobility and wage flexibility (Canagarajah \& Sethuraman, 2001: 2, 4). Social protection in the African setting is entrenched in the informal systems characterised by mutual support in the family networks and charities (IIiffe, 1987: 178).

Social protection programmes in Nigeria such as the Provident Funds and the Children Fund were responsible for the development, rehabilitation and feeding programmes especially following the Biafran war of 1967 to 1970 (IIiffe, 1987: 258). Kabeer, Cook, Chopra and Ainsworth (2010: 29) suggested that studies on social protection in developing countries should centre on the extension of social citizenship to some excluded social groups. This is because the test of effectiveness and improvement of social protection can only be done by studying those who do not benefit from the programme. This assertion reinforces the contribution of this study to knowledge on the subject of social protection in the informal building construction industry in Lagos Nigeria.

Besides, social protection is a sustainable means by which social justice can be provided for marginalised social groups and promote social inclusion and accountability (Jones \& Shahrokh, 2013: 10). In this connection, Canagarajah and Sethuraman (2001: 16) recommended that, in developing countries, social protection for workers in the informal industry must address risks, such as fall in income and risks associated with the status of the informality of employment. Nevertheless, it has been argued that the only means by which informal workers can access social protection is to organise (Lund \& Nicholson 2006: 5; Olusanya, 2014: 1).

Gonzales and Gregorio-Manasan (2002: 171) observe that social protection is well defined in the formal industry. In the Nigerian context, Nwabueze (1989: 2) observe that social protection has been neglected and is a pointer to distortion in national priorities. Thus, the issue of social protection is yet to receive adequate attention in the informal building construction industry in Nigeria.

\subsection{Social protection in the context of informal economy and subcontracting systems}

Subcontracting offers employers the opportunity to hire workers on a temporary basis thereby giving employers some flexibility on the determination of terms and conditions of employment. Li and Peng, (2006: 2) argue that there is a weakening of workers protection once there are large numbers of informal workers. Similarly, Canagarajah and Sethuraman (2001: 3) maintain that increased poverty as well as informalisation in labour 
markets, is threatening the provision of social protection in most countries, and that, despite best efforts, social protection is still inadequate in Nigeria. This is also the position of Holmes, Akinrimisi, Morgan, and Buck (2011: 1, 2012: Vi; Umukoro, 2013: 305). In this connection, Hagen-Zanker and Holmes (2012: Vi-Vii) explains that:

Nigeria currently spends less on social protection than many other African countries, despite its relative wealth. Social protection represented about $1.4 \%$ of consolidated government expenditure in 2009, compared with Kenya's spending of $6.2 \%$ of public expenditure in 2007/08. Moreover, two-thirds of this is allocated to civil servant pension and benefit schemes. Social protection is not seen as a top priority for the federal government, as reflected by the limited funding available for it. Some states are demonstrating interest and allocating resources to propoor social spending, in general, and, social protection, in particular (e.g., Jigawa State) (Hagen-Zanker \& Holmes, 2012: Vi-Vii).

This assertion means that addressing the problem of inadequate investment in social protection would require an overarching policy framework, which would serve as clear guides on the roles of federal, and state governments in the design and implementation of social protection programmes. Also, it is suggested that the role of the local government councils should be articulated, as they are more likely to be more active in these spheres.

Furthermore, Li and Peng (2006: 3) showed that the framework for social protection must take into account both work and status related risks, noting that the labour subcontracting systems, even though it plays a pivotal role in the supply of labour, also contributes to the high risks workers face, specifically in the construction industry. This myriad of challenges particularly in a situation where there is no contract of employment has been highlighted as follows:

Trust, without a contract, makes it difficult to be sure workers will be paid on time, or at all, or have any chance of compensation for damages. It is also related to persistent unemployment, which, in turn, affects the ability of workers to file complaints and be effectively protected. Jobs in construction also bring along high risks of injuries, especially when health and safety standards are not met. Regarding claiming unpaid salaries, the labour subcontractor systems also creates difficulties for those trying to implement policies to improve worker securities. Many researchers called for more creative methods to protect the workers. However, as shown in this research, the problems faced by these workers result from the organisation of the industry (Li \& Peng, 2006: 15).

This narrative shows that unemployment affects the willingness of workers to protest hostile working conditions. Li and Peng (2006: 17) cautioned, however, that this myriad of problems, particularly those that confronted rural construction workers in Chinese cities could not be solved with a rapid top-down policy, due to the complex interaction between social policies, industrial organisation and the process of rapid urbanisation.

However, Eme and Ugwu (2011: 2) have noted that the Nigerian Pension Reform Act (2004) translates into improved social security planning for retired workers and their families to achieve a degree of economic security. Nevertheless, the Pension Reform Act (2014) introduced changes, such as: increase in the minimum number of employees required to make contributions under the Act, increase in the minimum contribution into the scheme and the imposition of fines and penalties on Pension Fund Administrators (PFAs) for failure to meet their obligations to contributors as well as violation of the provisions of the Act (Price Waterhouse Coopers 2014: 1). These additional requirements should facilitate the inclusion of the excluded, but the key to success will lie in ensuring compliance from all the parties involved.

\section{Methods}

The research design adopted for this study was a crosssectional research design while the strategy employed was survey design. The cross-sectional design was adopted to observe the study population at a point in time (Levin, 2006: 24). This study was conducted in Lagos State, Nigeria, which has a population of about 21 million (Lagos State Government, 2017). Lagos State is divided into 37 Local Development Areas, 20 Local Government Areas and 5 Administrative Divisions, namely: Ikeja, Lagos, Ikorodu, Badagry and Epe (Lagos State Government, 2017; Oteri \& Ayeni, 2016: 2). The concentration of economic activities, large population and the resulting demand for building construction in Lagos State makes the city suitable for this study.

The population of this study comprised workers drawn from building construction sites, which possessed an approved building plan in Lagos State. It was necessary to use sites with approved building plans because as at the time this study commenced, the total number of building construction workers in Lagos State could not be ascertained. These approved building plans therefore provided information on active sites in Lagos where workers could be found. The records of approved building plans between 2007 and 2013 were retrieved from the Lagos State Physical Planning Permit Authority. The period 2007 through 2013 relates only to data for building construction sites considered as sample frame of the study and not the time when workers were observed. The population were informal workers artisans, including Carpenters, Blocklayers, Iron-Benders, Welders, Labourers, Machine Operators, Electricians, Plumbers, Plasterers, Painters and Tilers. Table 1 shows approved building plans between 2007 and 2013 across 20 Local Government Areas.

The study adopted Yamane's (1967) formula for sample size determination, which was adapted as follows:

$$
\begin{gathered}
n=\frac{N}{1+N\left(e^{2}\right)} \\
\text { Where }: n=\text { Sample Size } \\
N=\text { Population } \\
e=\text { Sampling Error }
\end{gathered}
$$


Table 1: Number of Building Plan Approvals in Lagos State: 2007-2013

\begin{tabular}{|c|c|c|c|c|c|c|c|c|c|}
\hline \multirow{2}{*}{$\mathbf{S} / \mathbf{N}$} & \multirow{2}{*}{ Local Government Areas } & \multicolumn{8}{|c|}{ Number of Planning Approvals } \\
\hline & & 2007 & 2008 & 2009 & 2010 & 2011 & 2012 & 2013 & TOTAL \\
\hline 1 & Agbado/Ipaja & 36 & 8 & 19 & 30 & 37 & 51 & 42 & 223 \\
\hline 2 & Agege & 117 & 16 & 31 & 88 & 173 & 160 & 130 & 715 \\
\hline 3 & Alimosho & 148 & 14 & 41 & 72 & 74 & 75 & 83 & 507 \\
\hline 4 & Amuwo-Odofin & 187 & 32 & 112 & 137 & 133 & 112 & 70 & 783 \\
\hline 5 & Apapa & 25 & 6 & 6 & 14 & 13 & 9 & 16 & 89 \\
\hline 6 & Badagry & 16 & 4 & 2 & 8 & 5 & Nil & Nil & 35 \\
\hline 7 & Eko & 17 & 4 & 9 & 17 & 25 & 22 & 7 & 101 \\
\hline 8 & Epe & 120 & 4 & 2 & 5 & 1 & 4 & 2 & 138 \\
\hline 9 & Eti-Osa & 705 & 384 & 403 & 554 & 394 & 407 & 395 & 3242 \\
\hline 10 & Ibeju-Lekki & 8 & 1 & 5 & 4 & 7 & 25 & 38 & 88 \\
\hline 11 & Ikeja & 139 & 61 & 105 & 122 & 120 & 110 & 213 & 870 \\
\hline 12 & Ikoyi/Victoria Island & 350 & 75 & 95 & 147 & 166 & 163 & 135 & 1131 \\
\hline 13 & Ikorodu & 846 & 142 & 31 & 55 & 278 & 164 & 149 & 1665 \\
\hline 14 & Kosofe & 374 & 167 & 302 & 293 & 180 & 184 & 142 & 1642 \\
\hline 15 & Mushin & 55 & 15 & 21 & 16 & 25 & 33 & 33 & 198 \\
\hline 16 & Oshodi-Isolo & 316 & 42 & 85 & 108 & 146 & 85 & 78 & 860 \\
\hline 17 & Ojo & 58 & 4 & 15 & 17 & 31 & 21 & 22 & 168 \\
\hline 18 & Somolu & 97 & 15 & 38 & 39 & 28 & 52 & 37 & 306 \\
\hline 19 & Surulere & 46 & 28 & 39 & 40 & 50 & 47 & 35 & 285 \\
\hline 20 & Yaba & 62 & 35 & 60 & 85 & 63 & 38 & 42 & 385 \\
\hline & TOTAL & 3722 & 1057 & 1421 & 1851 & 1949 & 1762 & 1669 & 13431 \\
\hline
\end{tabular}

The selection of 388 building construction sites from 13,431 obtained with the use of Yamane's (1967) formula provided a basis for identification of the eligible members of the study population. Probability sampling technique was adopted in the process of selecting the sample size for this study to afford each unit of the population equal chance of being selected (Kelley, Clark, Brown, \& Sitzia, 2003: 264). Thus, the probability sampling techniques adopted in the process of selecting the sample size for this study comprised the stratified and simple random techniques. The stratified sampling technique was used to select sites from five Administrative Divisions while the simple random sampling technique was used to select respondents from the sites. The research respondents comprised ten percent of workers on 388 building construction sites in Lagos State, Nigeria. Therefore, 388 sites produced 908 respondents as shown in Table 2.

Table 2: Sample Size by Administrative Division

\begin{tabular}{clcc}
\hline S/N & \multicolumn{1}{c}{$\begin{array}{c}\text { Administrative } \\
\text { Division }\end{array}$} & $\begin{array}{c}\text { No of } \\
\text { Sites }\end{array}$ & $\begin{array}{c}\text { Sample } \\
\text { Size }\end{array}$ \\
\hline 1 & Ikeja & 152 & 309 \\
2 & Lagos & 152 & 264 \\
3 & Badagry & 29 & 116 \\
4 & Ikorodu & 48 & 191 \\
5 & Epe & 7 & 28 \\
\hline \multicolumn{2}{r}{ Total } & $\mathbf{3 8 8}$ & $\mathbf{9 0 8}$ \\
\hline
\end{tabular}

The structured questionnaire was utilised to elicit quantitative data from 908 respondents, while Key Informant Interviews (KIIs) were conducted for 50 subcontractors across five Administrative Divisions in Lagos State, Nigeria. Quantitative data collected were examined, coded, entered and analysed using SPSS version 20.1. The nature of data gathered through the questionnaire dictated that descriptive and inferential statistics be employed in the analysis. Descriptive tools used included frequency distribution tables and simple percentages. Also, correlation analysis was used to test the hypothesis formulated. Also, content and narrative analyses were employed in the analysis of qualitative data. The tools find relevance in qualitative research data or open-ended questions and have been combined to deepen the analysis in this study.

\section{Results and Discussions}

4.1 Socio-economic and demographic characteristics of building construction workers

The socioeconomic and demographic characteristics of the respondents on building construction sites in Lagos State, Nigeria are displayed in Table 3. The data shows that 94.4 percent of the respondents were male; indicating that the building construction is a male dominated industry and may be linked to the physical requirements of jobs in the industry (Jacka, 1997: 22).

The data also shows that 28.6 percent of the respondents were bricklayers, which indicates that bricklayers are required in large numbers throughout the building construction process. Also, a limited number of machine operators are needed (3.3 percent). Therefore, the skilled labour demand is associated with nature of service provided. Over half of the workers (58.7) were married, a pointer to a possible sense of responsibility requiring that they continue to work to earn a living to support their families. A majority of the respondents $(60.4$ percent) had secondary school education, which makes them eligible to take on other jobs in which they may be interested.

A majority of the respondents were from the southern states (84.6 percent). Indigenes from the northern states 
constitute 12.4 percent, while 3.0 percent originated from neighbouring countries such as Benin Republic, Cotonou, Ghana and Togo. These results from the study conducted in Lagos State, reveals that most building construction workers stayed and found work around or in their states of origin. This suggests that provision of social protection measures by State Governments may be an incentive for workers to continue to seek employment in their states of origin. Besides, this would not only benefit the workers, but it would also contribute to economic activities in the State.

Table 3: Demographic Characteristics of Building Construction Workers

\begin{tabular}{lc}
\hline \multicolumn{1}{c}{ Variable } & $\%$ \\
\hline Sex & \\
Male $(n=857)$ & 94.4 \\
Female $(n=51)$ & 5.6 \\
\hline Highest level of Education & \\
Primary School $(n=241)$ & 26.5 \\
Secondary School $(n=548)$ & 60.4 \\
Technical College $(n=72)$ & 7.9 \\
No Education $(n=47)$ & 5.2 \\
\hline Nature of work on site & \\
Carpentry $(n=108)$ & 11.9 \\
Bricklaying $(n=260)$ & 28.6 \\
Iron Bending $(n=78)$ & 8.6 \\
Aluminium Works $(n=61)$ & 6.7 \\
P.O.P $(n=68)$ & 7.5 \\
Plumber $(n=49)$ & 5.4 \\
Electrician $(n=46)$ & 5.1 \\
Machine Operator $(n=30)$ & 3.3 \\
Labourers $(n=208)$ & 22.9 \\
\hline Marital Status & \\
Single $(F=353)$ & 38.9 \\
Married $(F=533)$ & 58.7 \\
Divorced/Separated/Widowed $(F=22)$ & 2.4 \\
\hline State of Origin & \\
North-Central $(103)$ & 11.3 \\
North-East $(2)$ & 0.2 \\
North-West $(8)$ & 0.9 \\
South-East $(88)$ & 9.7 \\
South-South $(89)$ & 3.0 \\
South West $(591)$ & \\
Foreign Nationals $(27)$ & \\
\hline
\end{tabular}

\subsection{Subcontracting systems in the building construction industry}

Table 4 shows the profile of subcontracting systems in the building construction industry. The data shows that the subcontractor hired almost half of the workers (44.6 percent), indicating that subcontractors are employers of labour the building construction industry in Lagos State. A majority of the respondents (89.1 percent) affirmed that their hirer was their employer, revealing that workers were directly responsible to the employers, who control and direct the worker in line with oral, written or implied a contract for work and is obligated to pay wages for work done on site. The distinction between 'hirer' and 'employer' was necessary to determine whether subcontractors on building construction sites merely supplied labour to the users or engaged workers to execute their subcontract on the sites.

Also, the responsibility for quality control and timely delivery of work on site were attributed to the subcontractor and contractor by 40.0 percent and 38.2 percent of the respondents respectively. Similarly, 46.5 percent got their wage from the subcontractor. Thus, the responsibility for quality assurance and collection of wage from the subcontractor confirms the important roles of subcontractors in the building construction industry.

Table 4: Subcontracting Systems in Building Construction Industry

\begin{tabular}{lc}
\hline \multicolumn{1}{c}{ Variable } & $\%$ \\
\hline Hirer & \\
Subcontractor $(n=405)$ & 44.6 \\
Contractor $(n=326)$ & 35.9 \\
Owner $(n=135)$ & 14.9 \\
Other $(n=42)$ & 4.6 \\
\hline Hirer same as Employer & \\
Yes $(n=809)$ & 89.1 \\
No $(n=99)$ & 10.9 \\
\hline Responsibility for quality control & \\
Subcontractor $(n=363)$ & 40.0 \\
Contractor $(n=317)$ & 34.9 \\
Owner $(n=128)$ & 14.1 \\
Other $(n=100)$ & 11.0 \\
\hline Responsibility for timely delivery of work & \\
Subcontractor $(n=347)$ & 38.2 \\
Contractor $(n=316)$ & 34.8 \\
Owner $(n=137)$ & 15.1 \\
Other $(n=108)$ & 11.9 \\
\hline Source of wage & \\
Subcontractor $(\mathrm{n}=422)$ & 46.5 \\
Contractor $(\mathrm{n}=320)$ & 35.2 \\
Owner $(\mathrm{n}=128)$ & 14.1 \\
Other $(\mathrm{n}=38)$ & 4.2 \\
\hline
\end{tabular}

\subsection{Social protection in the building construction industry}

Table 5 reveals variables associated with social protection in the building construction industry. It covers the proportion of building construction workers who enjoyed social protection, including assistance from government and employer. The findings reveal that a significant percentage of the workers (97.9 percent) did not receive any assistance from the government. Similarly, 91.4 percent stated that they did not receive assistance from their employers while 86.9 percent indicated that they did not have access to free or subsidised health care services. However, self/home treatment is very popular with the workers (48.1 percent)

Also, the proportion of workers who patronised private hospitals (31.3 percent) was higher than those who visited government hospitals (16.7 percent). Since workers seldom patronised public hospitals, they hardly benefited from subsidised medical services available. Conversely, it is not clear if services provided by government hospitals is sufficient to cater to the needs of the large population of workers in the informal sector. 
Furthermore, the data reveals that 11.2 percent of the workers had no savings; the majority (37 percent) saved daily; 29.4 percent saved weekly, while 22.4 percent saved monthly. Nevertheless, the pattern of savings is a function of earnings (Keynes, 1936). These findings demonstrate the deficit in social protection in the informal building construction industry in Nigeria.

However, some respondents acknowledged to receiving free eye check-ups from Non-Governmental Organisations (NGOs) and some assistance from the government, including food items at the local government, free eye test, free medical care, free mosquito nets and donation of basic equipment by members of the legislative arm of government representing a particular locality. The assistance from Local Government Councils and Legislators are usually funded through allocations from the federal government. Also, respondents also acknowledged the role of the Nigerian Labour Congress in the fight for an increase in pay and improvement of working conditions in the building construction industry. Despite all these provisions by the government, the reason why the majority of the workers felt that they did not receive any assistance from government may be that their expectations were at variance with the provisions by the government.

Table 5: Social Protection Experience in the Building Construction Industry

\begin{tabular}{lc}
\hline \multicolumn{1}{c}{ Variable } & $\%$ \\
\hline Government Assistance & \\
Yes $(n=20)$ & 2.1 \\
No $(n=888)$ & 97.9 \\
\hline Employers' Assistance & \\
Yes $(n=78)$ & 8.6 \\
No $(n=830)$ & 91.4 \\
\hline Access to free or subsidised medical care & \\
Yes $(n=119)$ & 13.1 \\
No $(n=789)$ & 86.9 \\
\hline Remedy to accident on site & \\
Self $/$ Home Treatment $(n=437)$ & 48.1 \\
Government Hospital $(n=152)$ & 16.7 \\
Private Hospital $(n=2847)$ & 31.3 \\
Other $(n=35)$ & 3.9 \\
\hline Pattern of savings & \\
None $(n=102)$ & 11.2 \\
Daily $(n=336)$ & 37.0 \\
Weekly $(n=267)$ & 29.4 \\
Monthly $(n=203)$ & 22.4 \\
\hline
\end{tabular}

Findings also reveal that employers/subcontractors in the building construction industry sometimes gave assistance, such as the following to their workers: useful advice, accommodation, feeding, bonus for job well done, cash (apart from salary), cash for medical care, supply of equipment and materials for the work, supply of mobile phones, end-of-year bonuses; occasional provision of transportation after work; help to secure other jobs; provision of tips and stipends/pocket money when payment is delayed; payment of children's school fees and other incentives and gifts on special occasions, e.g., birthdays, child-naming, burial of relatives, etc. However, only a small percentage of the workers ( 8.6 percent) attested to receiving these forms of assistance from their employers. This finding further suggests that a majority of informal building construction workers have no access to social protection and that only a small number of employers offer their employees some help.

The results on the profile of social protection coverage in the building construction industry provide evidence for Wells' (2006:10) assertion that construction workers in the developing world have neither guarantee of permanent employment nor protection against periods of unemployment, sickness or provision for old age.

Evidence from subcontractor interviews in Table 6 shows the forms of assistance provided for building construction workers. The most common form of aid (46 percent) was funding to procure health care services. Some of the interviewees (20 percent) stated that they assisted when workers requested it, whereas 18 percent affirmed that they assisted workers with a right attitude to work. Some other subcontractors (6 percent) noted that they facilitated payment for their employees' accommodation and property acquisition. However, 10 percent indicated that they did not assist their workers. These findings suggest that decisions on forms of aid provided to workers were largely at the discretion of employers. Therefore, it is highly unrealistic to leave this critical decision area to private employers because it is a license for exploitation of workers, which means that public policy has a major role to play in this regard.

Table 6: Forms of Assistance Provided to Workers

\begin{tabular}{lc}
\hline \multicolumn{1}{c}{ Themes } & \% \\
\hline Support on request $(n=10)$ & 20 \\
Facilitating accommodation $(n=2)$ & 4 \\
Property acquisition $(n=1)$ & 2 \\
Selective support for workers with good & 18 \\
attitude $(n=9)$ & \\
Financial and Health Assistance $(n=23)$ & 46 \\
No assistance $(n=5)$ & 10 \\
\hline Total & $\mathbf{1 0 0}$ \\
\hline
\end{tabular}

\subsection{Test of Hypothesis}

To test the hypothesis, which states that there is no significant relationship between subcontracting systems and availability of social protection measures in the building construction industry, correlation analysis was carried out. The results in Table 8 indicate that there is an inverse and significant relationship between hirer and access to free or subsidised medical care $(\mathrm{r}=-.184 ; \mathrm{P}=$ 0.000 ); between situations where hirer is same as employer and pattern of savings $(\mathrm{r}=-.138 ; \mathrm{P}=0.000)$; between responsibility for quality control and pattern of savings $(\mathrm{r}=-.144 ; \mathrm{P}=0.000)$; between responsibility for timely delivery of work and access to free or subsidised medical care $(\mathrm{r}=-.105 ; \mathrm{P}=0.000)$, as well as pattern of savings $\mathrm{r}=-.183 ; \mathrm{P}=0.000)$; between source of wage and access to free or subsidised medical care $\mathrm{r}=-.199 ; \mathrm{P}=$ $0.000)$. These results suggest that subcontracting systems have an inverse and statistically significant relationship with access to free or subsidised medical care, the remedy to accident on site and pattern of savings. These results 
align with findings of previous studies that attest to a weakening of social protection where subcontracting meets informal workers (Canagarajah \& Sethuraman, 2001: 3; Li \& Peng, 2006: 2).

Table 8: Relationship between Subcontracting Systems and availability of Social Protection Measures in the Building Construction Industry

\begin{tabular}{|c|c|c|c|c|c|}
\hline Variables & $\begin{array}{c}\text { Government } \\
\text { assistance }\end{array}$ & $\begin{array}{c}\text { Employers' } \\
\text { assistance }\end{array}$ & $\begin{array}{c}\text { Access to free or } \\
\text { subsidised medical care }\end{array}$ & $\begin{array}{c}\text { Remedy to } \\
\text { accident on site }\end{array}$ & $\begin{array}{c}\text { Pattern of } \\
\text { savings }\end{array}$ \\
\hline \multicolumn{6}{|l|}{ welfare } \\
\hline Pearson Correlation & .010 & -.046 & $-.184 * *$ & -.065 & -.015 \\
\hline Sig. (2-tailed) & .765 & .169 & .000 & .051 & .655 \\
\hline $\mathrm{N}$ & 908 & 908 & 908 & 908 & 908 \\
\hline \multicolumn{6}{|c|}{ Hirer same as employer } \\
\hline Pearson Correlation & .051 & $.069 *$ & $.125 * *$ & $.117 * *$ & $-.138 * *$ \\
\hline Sig. (2-tailed) & .124 & .037 & .000 & .000 & .000 \\
\hline $\mathrm{N}$ & 908 & 908 & 908 & 908 & 908 \\
\hline \multicolumn{6}{|c|}{ Responsibility for quality control } \\
\hline Pearson Correlation & .041 & -.040 & $-.078 *$ & -.016 & $-.144 * *$ \\
\hline Sig. (2-tailed) & .218 & .232 & .019 & .624 & .000 \\
\hline $\mathrm{N}$ & 908 & 908 & 908 & 908 & 908 \\
\hline \multicolumn{6}{|c|}{ Responsibility for timely delivery of work } \\
\hline Pearson Correlation & .062 & -.053 & $-.105 * *$ & -.027 & $-.183 * *$ \\
\hline Sig. (2-tailed) & .061 & .112 & .002 & .425 & .000 \\
\hline $\mathrm{N}$ & 908 & 908 & 908 & 908 & 908 \\
\hline \multicolumn{6}{|l|}{ Source of wage } \\
\hline Pearson Correlation & .005 & -.054 & $-.199 * *$ & -.062 & -.003 \\
\hline Sig. (2-tailed) & .878 & .101 & .000 & .063 & .937 \\
\hline $\mathrm{N}$ & 908 & 908 & 908 & 908 & 908 \\
\hline
\end{tabular}

**. Correlation is significant at the 0.01 level (2-tailed).

*. Correlation is significant at the 0.05 level (2-tailed).

\section{Conclusions and Recommendation}

This study assessed the relationship between subcontracting systems and access of informal building construction industry workers to social protection measures in Lagos State, Nigeria. The study determined the types of assistance and benefits informal building construction workers receive from government as well as the kinds of assistance provided by employers for informal building construction workers.

This study has established that the prevalence of subcontracting systems in the building construction industry limits workers access to social protection measures. Although quantitative data showed that employees did not receive welfare benefits from Government or their employers, qualitative data revealed that workers enjoyed some social benefits from government and their employers. The workers, however, noted that these benefits were inadequate. These benefits include subsidised medical services, accommodation, feeding, the supply of mobile phones, end of year bonuses, and so forth.

In the light of the conclusions of this study, it is suggested that the building construction industry in Lagos State must not be left to 'self-regulate'. Therefore, an

\section{References}

Adejumo, G. O. and Azuh, D. 2013. Patterns of workplace violence among women in informal sector in appropriate legislative instrument should be developed to address the challenges posed by subcontracting systems about access to social protection measures in the informal building construction industry. This is necessary given that the nature of construction works dictate the engagement of subcontractors. Also, the government, particularly at the local levels should promote and support community-based social insurance schemes for informal sector workers. The inability of the researcher to ascertain the total number of informal building construction workers posed a limitation for the study and made the process of data gathering very tedious. However, this limitation afforded the opportunity for this study to provide a basis for the estimation of the number of informal building construction workers in Lagos State, which should be useful to future researchers. Furthermore, the number of workers on site at the time data was gathered determined the sample from each location. The researcher visited the sites on days when workers worked in large numbers on site. Considering that this study is limited to Lagos State, it is suggested that future research should cover the major geopolitical zones in Nigeria for a more robust evidence and conclusion.

South West, Nigeria. International Journal of Social Sciences and Humanities Reviews, 4(1): 9-13.

Adenuga, O. A. 2013. Factors affecting quality in the delivery of public housing projects in Lagos State, 
Nigeria. International Journal of Engineering and Technology (IJET), 3(3):332-344.

Ajayi, D. D. 2007. Recent trends and patterns in Nigeria's industrial development. Africa Development, XXXII (2):139-155.

Akinwale, A.A. 2014. Precarious working conditions and exploitation of workers in the Nigerian informal economy. Social Science Diliman, 10(1):117-146.

Aronson, J. E. and Zionts, S. Ed. 2008. Operations research: methods, models and applications. USA: Quorum Books.

Arrow, K.J. 1971. Essays in the theory of risk bearing. Chicago: Markham Publishing Company.

Atamturk, A. and Hochbaum, D. S. 2001. Capacity acquisition, subcontracting, and lot sizing. Management Science, 47(8):1081-1100.

Azari-Rad, H. Philips, P. and Thompson-Dawson, W. 2014. Subcontracting and injury rates in construction. Employment Relationships in Construction, 240-247. [Online].

https://www.google.com.ng/?client=safari\&channel=ma c_bm\&gws_rd=cr\&ei=Qcw5Wf-

ZKIHXU6OlvpgE\#channel=mac_bm\&q=Azari-

Rad, +H.+Philips,+P.+and+Thompson-

Dawson,+W.+2014.+Subcontracting+and+injury+rates+ in+construction. (25 January 2017)

Barrientos, A. and Hulme, D. 2008. Social protection for the poor and poorest in developing countries: Reflections on a quiet revolution. BWPI Working Paper 30.

[Online].

https://www.unicef.org/spanish/socialpolicy/files/Social_

Protection_for_the_Poor_and_Poorest_in_Developing_C ountries.pdf (10 June 2017)

Boland, M.A. Golden, B.B. and Tsoodle, L.J. 2008. Agency theory issues in the food processing industry. Journal of Agricultural and Applied Economics, 40(2): 623-634.

Canagarajah, S. and Sethuraman S.V. 2001. Social protection and the informal industry in developing countries: challenges and opportunities. Washington D.C., USA: The World Bank, Social Protection Unit.

Chen, M. Vanek, J. and Heintz, J. 2006. Informality, gender and poverty: a global picture. Economic and Political Weekly, 41(21): 2131-2139. [Online]. www.jstor.org/stable/4418269 ) 30June 2014(

Cohen, A. and Baruch, Y. 2010. An agency theory perspective of the Israeli labour market segmentation: past, present, and future. Human Resource Management Review, 20:186-193.

Eisenhardt, K.M. 1989. Agency theory: an assessment and review. Academy of Management Review, 14: 57-74. [Online]. http://www.jstor.org/stable/258191 (08 June 2017)

Eme, O.I. and Ugwu, S.C. 2011. The laws and administration of retirement in Nigeria: a historical approach. Kuwait Chapter of Arabian Journal of Business and Management Review, 1(2): 1-10.

Enshassi, A. Choudhry, R.M. Mayer, P.E. and Shorman, Y. 2008. Safety performance of subcontractors in the Palestinian construction industry. Journal of Construction in Developing Countries, 13(1): 51-62.

Fagbenle, O. I. and Adesanya, D. A. 2014. Millennium development goals and the impact of registration on the performance of construction subcontractors in Nigeria. [Online].

http://eprints.covenantuniversity.edu.ng/3230/1/Millenni um\%20Development.pdf (02 July 2017)

Gasset, J. O. n.d. Labour market equilibrium. [Online]. https://www.hks.harvard.edu/fs/gborjas/publications/boo ks/LE/LEChapter4.pdf (11 June 2017)

Gonzales, E.T. and Gregorio-Manasan, R. 2002. Social protection in the Philippines. In: Erfried, A., Hauff, V. and Marei, J. ed. Social protection in Southeast Asia. Singapore: Friedrich Ebert Stiftung, pp. 171-229.

Hagen-Zanker, J. and Holmes, R. 2012. Social protection in Nigeria: synthesis report. Westminster Bridge Road, London: Overseas Development Institute.

Heintz, J. and Valodia, I. 2008. Informality in Africa: a Review. WIEGO Working Paper No 3. [Online]. http://www.inclusivecities.org/wp-

content/uploads/2012/07/Heintz_WIEGO_WP3.pdf (10 June 2017)

Holmes, R. Akinrimisi, B. Morgan, J. and Buck, R. 2011. Social protection in Nigeria: an overview of programmes and their effectiveness. Westminster Bridge Road, London: Overseas Development Institute.

Holmes, R. Akinrimisi, B. Morgan, J. and Buck, R. 2012. Social protection in Nigeria: mapping programmes and their effectiveness. Westminster Bridge Road, London: Overseas Development Institute,

IIiffe, J. 1987. The African poor: a history. New York: Cambridge University Press

ILO 2000. World labour report 2000: income security and social protection in a changing world. Geneva, Switzerland: International Labour Organization.

ILO 2001. The construction industry in the twenty-first century: its image, employment prospects and skills requirement. Geneva: International Labour Office.

Jacka, T. 1997. Women's work in rural China: change and continuity in an era of reform. United Kingdom: Cambridge University Press.

Jensen, M. \& Meckling, W. 1976. Theory of the firm: managerial behaviour, agency costs, and ownership structure. Journal of Financial Economics, 3(4): 305-360.

Jones, N. and Shahrokh, T. 2013. Social protection pathways: shaping social justice outcomes for the most marginalised, now and post-2015. Westminster Bridge Road, London: Overseas Development Institute.

Kabeer, N. Cook, S. Chopra, D. and Ainsworth, P. 2010. Social protection in Asia: research findings and policy lessons. [Online]. https://www.ids.ac.uk/files/dmfile/SPASynthReportweb. pdf (10 June 2017)

Kallay, B. 2012. Contract theory of firm. Economics and Sociology, 5(1): 39-50.

Kelley, K. Clark, B. Brown, V. and Sitzia, J. 2003. Methodology matters: good practice in the conduct and reporting of survey research. International Journal for Quality in Health Care, 15(3): 261-266.

Keynes, J.M. 1936. General theory of employment, interest and money. London: Cambridge University Press, for Royal Economic Society.

Kimura, F. 2002. Subcontracting and the performance of small and medium firms in Japan. Small Business Economics, 18(1/3):163-175. 
Lagos State Government 2017. About Lagos. [Online]. https://lagosstate.gov.ng/about-lagos/ (04/06/2017)

Levin, K.A. 2006. Study design iii: cross-sectional studies. Evidenced Based Dentistry, 7:24-25.

Li, B. and Peng, H. 2006. The social protection of rural workers in the construction industry in urban China. London: Centre for Analysis of Social Exclusion, London School of Economics.

Loh, W.H. and Ofori, G. 2000. Effect of registration on performance of construction subcontractors in Singapore. Engineering Construction and Architectural Management, 7(I):29-38.

Lund, F. and Nicholson, J. 2006. Tools for Advocacy: social protection for informal workers. [Online]. http://www.wiego.org/sites/default/files/resources/files/T ools-For-Advocacy-Social-Protection-for-InformalWorkers.pdf (18 April 2017).

Manu, P. Ankrah, N. Proverbs, D. Suresh, S. and Adukpo, E. 2011. Managing the adverse health and safety influence of subcontracting: Findings of a qualitative inquiry. In: Laryea, S. Leiringer, R. and Hughes, W. ed. Proceedings of the West Africa Built Environment Research (WABER) Conference, 19-21 July 2011, Accra, Ghana. pp. 735-744.

Marshall, A. (1890). Principles of economics. London: Macmillan.

Mill, J. S. (1808). Commerce defended. London: C. and R. Baldwin.

Mill, J. S. (1844). Essays on some unsettled questions of political economy. London: John W. Parker.

Mill, J. S. (1848). Principles of political economy. London: John W. Parker.

National Bureau of Statistics 2016. Job creation survey, 4th quarter 2015 and 1st quarter 2016 summary finding and selected tables. [Online]. www.nigerianstat.gov.ng/download/433 (10 February 2017).

Nwabueze, B.O. 1989. Social security in Nigeria. Lagos: Institute of Advanced Legal Studies.

Ogunsanmi, O. E. 2015. Comparisons of procurement characteristics of traditional and labour-only procurements in housing projects in Nigeria. Covenant Journal of Research in the Built Environment (CJRBE), 3(2): 53-67.

Ohnuma, D. K. Pereira, S.R. and Cardoso, F. F. 2000. The role of subcontractors in the competitiveness of building companies and the integration of value chains. [Online].

http://www.pcc.usp.br/files/text/personal_files/francisco _cardoso/papercibchilew62subcontractors.pdf (11 June 2017)

Okafor, E. E. 2012. Non-standard employment relations and implications for decent work deficits in Nigeria. African Research Review, 6(3): 93-108.

Olusanya, O.A. 2014. Decent work deficits in the Nigerian informal economy. African Journal of Microfinance and Enterprise Development (AJMED), 4(1): $1-18$

Oteri, A. U. and Ayeni, R. A. 2016. The Lagos mega city. [Online] http://eaumega.org/wpcontent/uploads/2016/05/EN-Lagos-Monograph.pdf (04 June 2017).
Pigou, A. C. 1912. Wealth and welfare. London: Macmillan.

Pigou, A. C. 1944. Lapses from full employment. Macmillan, London.

Price Waterhouse Coopers 2014. Pension reform Act 2014: Key highlights and salient points. Nigeria Tax Alert. [Online]. http://www.pwc.co.za/en/assets/pdf/thenew-pension-reform-act-2014-key-highlights-salientpoints-1.pdf (24 January 2017).

Ricardo, D. 1817. On principles of political economy and taxation. In: Sraffa, P. and Dobb, M. H. ed. 1951. Works and correspondence of David Ricardo, Volume 1, Cambridge: Cambridge University Press.

Ricardo, D. 1971. The works and correspondence of David Ricardo, volume II: notes on Malthus' principles of political economy. Cambridge: Cambridge University Press.

Say, J. B. 1834. A treatise on political economy. New York: Augustus M. Kelley Publishers.

Simons, R. and Lake, Z. 2005. Options for generating indicators on informal employment using the labour force survey - part one: an informal sector module for the labour force survey. [Online]. http://www.ilo.org/wcmsp5/groups/public/---americas/--ro-lima/---sro-

port_of_spain/documents/meetingdocument/wcms_3062 70.pdf (20 June 2015).

Tanaka, H. 2012. Personality in industry: the human side of a Japanese enterprise. Great Britain: Bloomsbury Publishing Plc.

Tanzi, V. 1999. Uses and abuses of estimates of the underground economy. The Economic Journal, 109: 338347.

[Online].

http://www.jstor.org/discover/10.2307/2566007?uid=373 8720 \&uid $=2134 \&$ uid $=2$ \&uid $=70 \&$ uid $=4 \&$ sid $=2110343$ 0209611 (20 June 2015).

Umukoro, N. 2013. Poverty and social protection in Nigeria. Journal of Developing Societies, 29(3): 305-322.

Usdiken, B. Sozen, Z. and Enbiyaoglu, H. 1988. Strategies and boundaries: Subcontracting in construction. Strategic Management Journal, 9(6): 633637.

Wamuthenya, W. R. 2010. Determinants of employment in the formal and informal sectors of the urban areas of Kenya. AERC Research Paper 194, is

Wells, J. 2007. Informality in the construction sector in developing countries. Construction Management and Economics, 25: 87-93. [Online]. https://www.academia.edu/3999392/Informality_in_the_ construction_sector_in_developing_countries?auto=dow nload (12 June 2017).

Wells, J. 2006. Labour subcontracting in the construction industries of developing countries: an assessment from two perspectives. Journal of Construction in Developing Countries, 11(1):17-36.

Wilson, R.B. 1968. The theory of syndicates. Econometric, 36(1): 119-132.

Yamane, T. 1967. Statistics: an introductory analysis. New York: Harper and Row. 